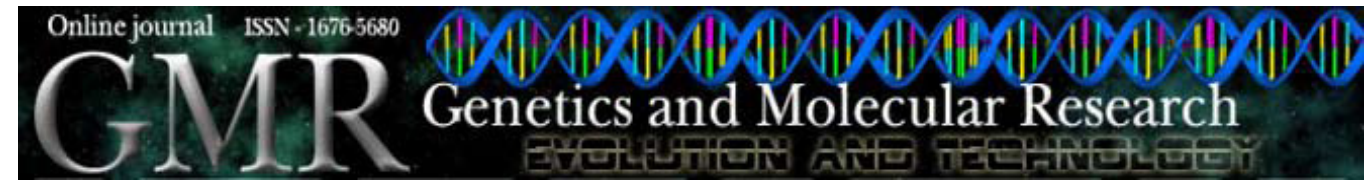

\title{
$X R C C 1$ polymorphisms and haplotypes in Mexican patients with acute lymphoblastic leukemia
}

\author{
J.P. Meza-Espinoza ${ }^{1}$, V. Peralta-Leal ${ }^{1}$, M. Gutierrez-Angulo ${ }^{2}$, \\ N. Macias-Gomez ${ }^{3}$, M.L. Ayala-Madrigal ${ }^{4}$, P. Barros-Nuñez ${ }^{\text {, }}$ \\ J. Duran-Gonzalez ${ }^{6}$ and E. Leal-Ugarte ${ }^{1}$ \\ ${ }^{1}$ Unidad Academica de Ciencias de la Salud y Tecnologia, \\ Universidad Autonoma de Tamaulipas, Matamoros, Tamps, Mexico \\ ${ }^{2}$ Centro Universitario de los Altos, Universidad de Guadalajara, \\ Tepatitlan de Morelos, Jalisco, Mexico \\ ${ }^{3}$ Centro Universitario del Sur, \\ Universidad de Guadalajara, Cd. Guzman, Jalisco, Mexico \\ ${ }^{4}$ Centro Universitario de Ciencias de la Salud, \\ Universidad de Guadalajara, Guadalajara, Jalisco, Mexico \\ ${ }^{5}$ Centro de Investigacion Biomedica de Occidente, \\ Instituto Mexicano del Seguro Social, Guadalajara, Jalisco, Mexico \\ ${ }^{6}$ University of Texas at Brownsville, Brownsville, Texas, USA
}

Corresponding authors: E. Leal-Ugarte

E-mail: elugarte@uat.edu.mx

Genet. Mol. Res. 8 (4): 1451-1458 (2009)

Received September 11, 2009

Accepted October 7, 2009

Published December 1, 2009

ABSTRACT. We examined the influence of the Arg194Trp, Arg280His, and Arg399Gln polymorphisms of XRCCl (X-ray repair cross-complementing group 1) on the development of childhood acute lymphoblastic leukemia (ALL) in 120 ALL patients and 120 controls in Mexico. All of them were genotyped for these polymorphisms, using polymerase chain reaction. No significant differences in allele and genotype frequencies for any polymorphism were observed between patients and controls. Estimation of haplotypes showed the eight expected haplotypes (A-H), seven of which were found in both patients 
and controls; haplotype A (Arg-Arg-Arg) was the most common, whereas haplotypes $F$ and $G$ were absent in patients and controls, respectively. Haplotype B (Trp-Arg-Arg) was found to be associated with an increased risk of ALL (odds ratio $(\mathrm{OR})=1.95,95 \%$ confidence interval $(\mathrm{CI})=1.13-3.37 ; \mathrm{P}=0.016)$, particularly in males $(\mathrm{OR}=2.65$, $95 \% \mathrm{CI}=1.25-5.63 ; \mathrm{P}=0.01)$. Individually, the $194 \mathrm{Trp}, 280 \mathrm{His}$, and 399Gln alleles were not associated with significantly increased risk for ALL in these Mexican children.

Key words: Polymorphisms; Haplotypes; XRCC1;

Childhood acute lymphoblastic leukemia; Mexicans

\section{INTRODUCTION}

DNA repair systems maintain genome integrity, which is of vital importance for cellular functions. A failure of these systems has been associated with cancer, birth defects, and an accelerated rate of aging (Ronen and Glickman, 2001). Polymorphisms in DNA repair genes may result in deficient DNA repair, which in turn leads to cumulative genotoxic damage and increased cancer susceptibility (Krajinovic et al., 2002). The X-ray repair cross-complementing group 1 (XRCC1) protein participates in the DNA repair process by base excision repair. There are 21 single nucleotide polymorphisms in the XRCC1 gene that produce amino acid substitutions (Hubbard et al., 2009); three of them have been associated with cancer, including leukemia, but controversial results have been reported (Seedhouse et al., 2002; Hu et al., 2005; Joseph et al., 2005; Zhu et al., 2005; Matullo et al., 2006; Deligezer et al., 2007; Pakakasama et al., 2007; Batar et al., 2009). Such polymorphisms are rs 1799782 (Arg194Trp) localized in exon 6, rs25489 (Arg280His) in exon 9, and rs25487 (Arg399Gln) in exon 10 (Hubbard et al., 2009). Recently, association studies between these XRCC1 polymorphisms and childhood acute lymphoblastic leukemia (ALL) have been performed (Joseph et al., 2005; Zhu et al., 2005; Pakakasama et al., 2007; Batar et al., 2009). In this study, we searched for an association of the XRCC1 Arg 194Trp, Arg280His, and Arg399Gln polymorphisms with the development of childhood ALL in a Mexican population.

\section{MATERIAL AND METHODS}

\section{Study subjects}

One hundred and twenty consecutive children with ALL (116 with ALL-L1 and 4 with ALL-L2) diagnosed clinically and histopathologically at the Centro Medico Nacional de Occidente in Guadalajara, Jalisco, Mexico, and a control group composed of 120 healthy individuals randomly selected from blood donors were analyzed for the Arg194Trp, Arg280His, and Arg399Gln polymorphisms of the XRCC1 gene. Both groups were mestizos of the Mexican West (States of Jalisco, Colima, Michoacan, and Aguascalientes). The patient group, analyzed before treatment, was composed of 65 males and 55 females with an average age of seven years (range 1-14 years at diagnosis), and the control group included 84 males and 36 females. 
Informed written consent was obtained from all individuals, and the study was conducted in accordance with the guidelines of the Declaration of Helsinki.

\section{Methods}

Genomic DNA was extracted from peripheral blood of patients and of controls by the phenol-chloroform or GenomicPrep ${ }^{\mathrm{TM}}$ Blood DNA Isolation Kit (Amersham Bioscience; Piscataway, NJ, USA) procedure; a polymerase chain reaction-restriction fragment length polymorphism (PCR-RFLP) analysis was then performed. The primers used were 5'-GCCCCGTCCCAGGTA-3' and 5'-AGCCCCAAGACCCTTTCACT-3' for polymorphism Arg 194Trp, 5'-TTGTGCTTTCTCTGTGTCCA-3' and 5'-TCCTCCAGCCTTTTCTGATA-3' for Arg399Gln, and 5'-CCAGTGGTACTAACCTAATC-3' and 5'-CACTCAGCACCAGTAC CACA-3' for Arg280His. PCR-RFLP was carried out according to methods previously described (Butkiewicz et al., 2001; Zhang et al., 2005). The amplification program consisted of an initial denaturation at $94^{\circ} \mathrm{C}$ for 4 min and 35 cycles at $94^{\circ} \mathrm{C}$ for $30 \mathrm{~s}, 60^{\circ} \mathrm{C}$ for $30 \mathrm{~s}$ $\left(62^{\circ} \mathrm{C}\right.$ for $30 \mathrm{~s}$ for $\left.\mathrm{Arg} 280 \mathrm{His}\right)$, and $72^{\circ} \mathrm{C}$ for $30 \mathrm{~s}$, followed by a final elongation at $72^{\circ} \mathrm{C}$ for 4 min. The PCR products were 491 bp for Arg194Trp; 201 bp for Arg280His, and 615 bp for Arg399Gln. Cleavage with specific endonucleases for each polymorphism was done as follows; HpaII for Arg194Trp and Arg399Gln, and RsaI for Arg280His (Butkiewicz et al., 2001; Zhang et al., 2005) (see Figures 1, 2 and 3).

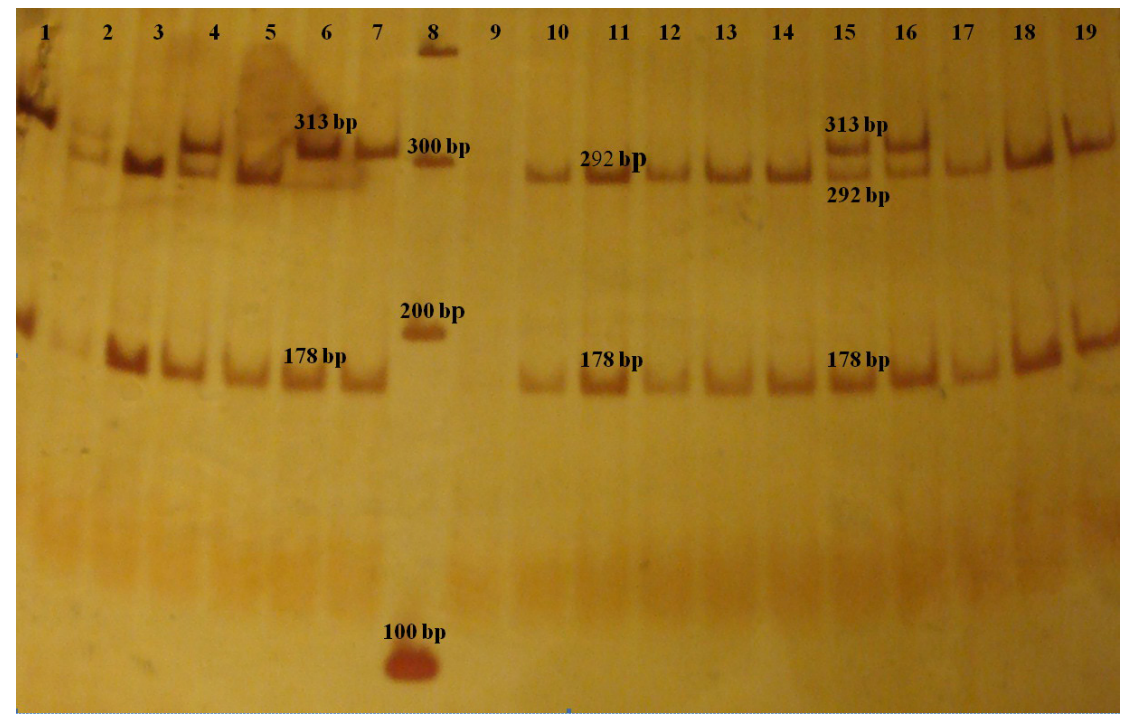

Figure 1. Polyacrylamide gel showing results of the XRCC1 Arg194Trp polymorphism in some individuals. Lanes 1, 6, and 7: Mutated homozygous (Trp/Trp). Lanes 2, 4, 15, and 16: Heterozygous (Arg/Trp). Lanes 3, 5, 10-14, and 17-19: Wild homozygous (Arg/Arg). Lane 8: 100-bp marker. Lane 9: Result not conclusive. Note: Cleavage with HpaII yielded fragments of 292, 178, and $21 \mathrm{bp}$ for the wild allele, and 313 and $178 \mathrm{bp}$ for the polymorphic allele. Fragments of 21 bp are not shown. 


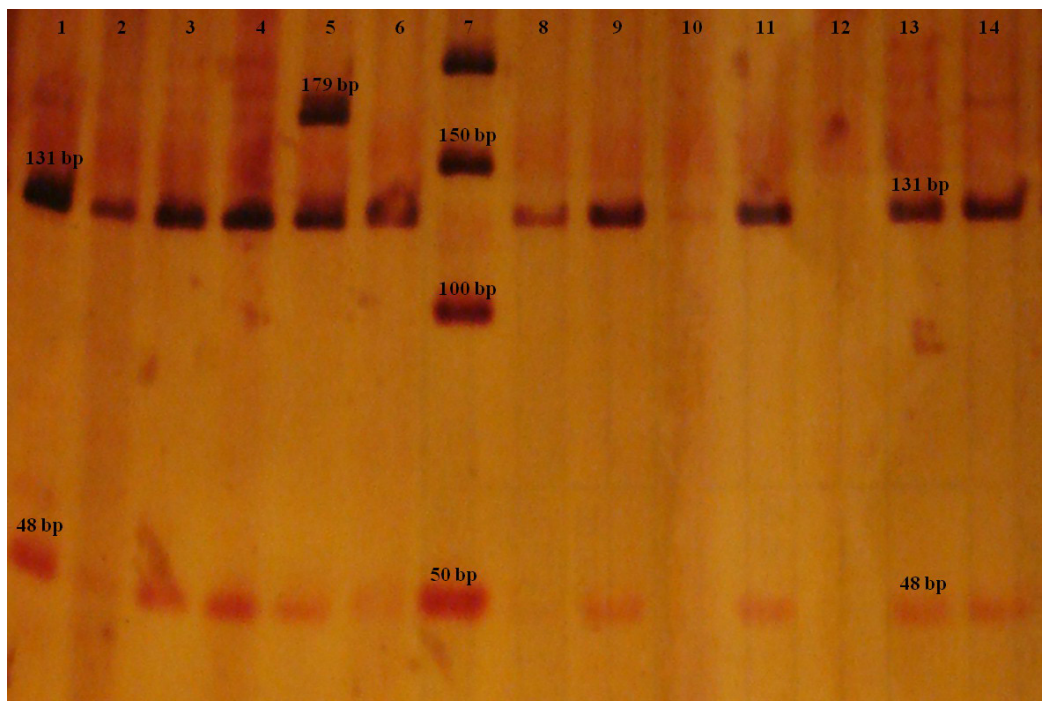

Figure 2. Polyacrylamide gel showing results of the XRCC1 Arg280His polymorphism in some individuals. Lanes 1-4, 6, 8-11, 13, and 14: Wild homozygous (Arg/Arg). Lane 5: Heterozygous (Arg/His). Lane 7: 50-bp marker. Lane 12: Without sample. Note: Digestion with RsaI rendered products of 131, 48, 14, and 8 bp for the wild allele, and 179, 14, and 8 bp for the polymorphic allele. Fragments of 14 and 8 bp are not shown.

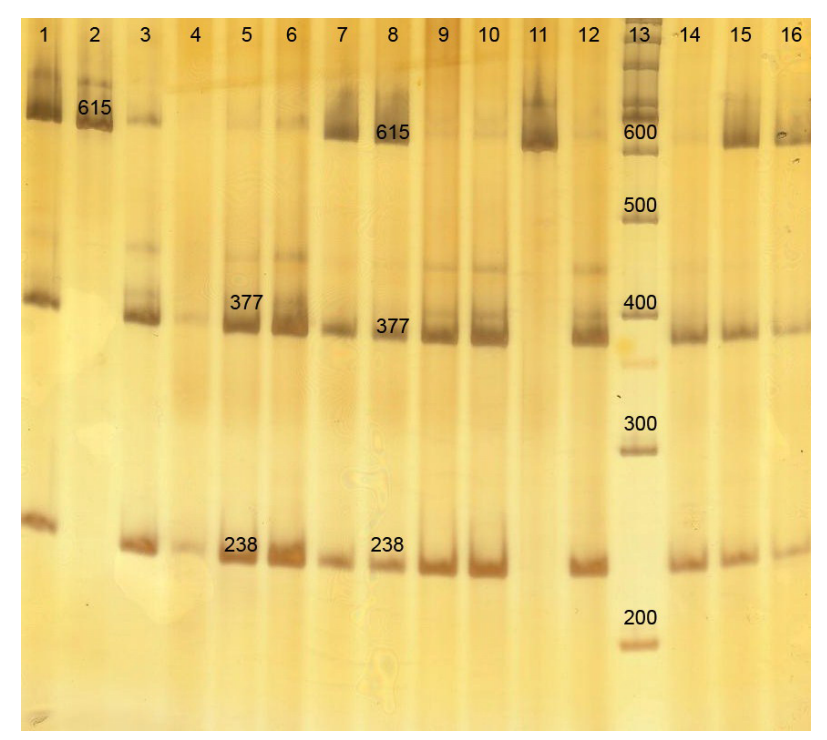

Figure 3. Polyacrylamide gel showing results of the XRCC1 Arg399Gln polymorphism in some individuals. Lanes 1, 7, 8, 15, and 16: Heterozygous (Arg/Gln). Lanes 2 and 11: Mutated homozygous (Gln/Gln). Lanes 3-6, 9, 10, 12 and 14: Wild homozygous (Arg/Arg). Lane 13: 100-bp marker. Note: Cleavage with HpaII produced fragments of 377 and $238 \mathrm{bp}$ for the wild allele and $615 \mathrm{bp}$ for the polymorphic allele. 


\section{Statistical analysis}

Statistical analysis was performed with the SPSS 10.0 for Windows software. Hardy-Weinberg equilibrium was evaluated by the Fisher exact test. Comparison of allele and genotype frequencies between patients and controls was carried out by the chi-square test. Risk of ALL was estimated calculating the odds ratio (OR) and 95\% confidence intervals $(95 \% \mathrm{CI})$. Moreover, analysis by gender was done contrasting allele frequencies between patients and controls. On the other hand, estimation of haplotypes was done with the Hapstat 3.0 software using the genotypic data, and evaluation of risk of ALL was performed. In all analyses, the wild alleles were taken as reference and the level of significance was defined as $\mathrm{P}<0.05$.

\section{RESULTS}

The allele and genotype frequencies are shown in Table 1. The allele frequencies of the three polymorphisms were consistent with Hardy-Weinberg equilibrium $(\mathrm{P}=$ 1.0 for Arg194Trp, $\mathrm{P}=0.70$ for Arg280His, and $\mathrm{P}=1.0$ for Arg399Gln). No significant differences in allele and genotype frequencies for any polymorphism were observed between patients and controls, although the polymorphic alleles were more frequent in patients (Table 1). The analysis by gender also showed no differences.

\begin{tabular}{|c|c|c|c|c|c|c|}
\hline Genotype & $\begin{array}{l}\text { Controls } \\
(\mathrm{N}=120)\end{array}$ & $\begin{array}{l}\text { Patients } \\
(\mathrm{N}=120)\end{array}$ & OR $(95 \% \mathrm{CI})^{1}$ & $\mathrm{P}^{1}$ & OR $(95 \% \mathrm{CI})^{2}$ & $\mathrm{P}^{2}$ \\
\hline \multicolumn{7}{|l|}{ Arg194Trp } \\
\hline $\mathrm{Arg} / \mathrm{Arg}$ & 86 & 80 & 1.0 (Reference) & & \multirow{3}{*}{$1.30(0.81-2.09)$} & \multirow{3}{*}{0.28} \\
\hline $\operatorname{Arg} / \operatorname{Trp}$ & 31 & 34 & $1.18(0.66-2.09)$ & 0.57 & & \\
\hline $\operatorname{Trp} / \operatorname{Trp}$ & 3 & 6 & $2.15(0.52-8.89)$ & 0.28 & & \\
\hline \multicolumn{7}{|l|}{$\operatorname{Arg} 280 \mathrm{His}$} \\
\hline $\mathrm{Arg} / \mathrm{Arg}$ & 88 & 87 & 1.0 (Reference) & & \multirow{3}{*}{$1.07(0.64-1.79)$} & \multirow{3}{*}{0.79} \\
\hline $\mathrm{Arg} / \mathrm{His}$ & 31 & 31 & $1.01(0.57-1.81)$ & 0.97 & & \\
\hline $\mathrm{His} / \mathrm{His}$ & 1 & 2 & $2.02(0.18-22.72)$ & 0.56 & & \\
\hline \multicolumn{7}{|l|}{ Arg399Gln } \\
\hline $\mathrm{Arg} / \mathrm{Arg}$ & 65 & 57 & 1.0 (Reference) & & \multirow{3}{*}{$1.28(0.86-1.90)$} & \multirow{3}{*}{0.23} \\
\hline $\mathrm{Arg} / \mathrm{Gln}$ & 47 & 51 & $1.24(0.73-2.11)$ & 0.43 & & \\
\hline $\mathrm{Gln} / \mathrm{Gln}$ & 8 & 12 & $1.71(0.65-4.48)$ & 0.27 & & \\
\hline
\end{tabular}

Comparison of genotype ${ }^{1}$ and allele ${ }^{2}$ frequencies between patients and controls. ${ }^{2}$ Wild alleles were taken as reference. Chi-square test.

We found the expected eight haplotypes (A-H), including seven in both patients and controls (Table 2); haplotype A (Arg-Arg-Arg) was the most common, whereas haplotypes F and $\mathrm{G}$ were absent in patients and controls, respectively. Only the four most frequent haplotypes were considered for analysis. Haplotype B (Trp-Arg-Arg) was associated with an increased risk of ALL $(\mathrm{OR}=1.95,95 \% \mathrm{CI}=1.13-3.37 ; \mathrm{P}=0.016)$ (Table 2), particularly in males $(\mathrm{OR}=2.65,95 \% \mathrm{CI}=1.25-5.63 ; \mathrm{P}=0.01)($ Table 3$)$. 


\begin{tabular}{lcccc}
\multicolumn{5}{l}{ Table 2. Haplotype frequencies of the three $X R C C 1$ polymorphisms in patients and controls. } \\
\hline $\begin{array}{c}\text { Controls } \\
\text { Haplotype }\end{array}$ & $\begin{array}{c}\text { Patients } \\
(\mathrm{N}=240)\end{array}$ & OR (95\%Cl) & $\mathrm{P}^{*}$ \\
\hline A Arg-Arg-Arg & 118 & 93 & 1.0 (Reference) & \\
B Trp-Arg-Arg & 28 & 43 & $1.95(1.13-3.37)$ & 0.016 \\
C Arg-Arg-Gln & 59 & 67 & $1.44(0.93-2.24)$ & 0.11 \\
D Arg-His-Arg & 28 & 2 & $1.37(0.75-2.49)$ & 0.31 \\
E Trp-Arg-Gln & 2 & 0 & $\mathrm{ND}$ & $\mathrm{ND}$ \\
F Trp-His-Arg & 5 & 6 & $\mathrm{ND}$ & $\mathrm{ND}$ \\
G Arg-His-Gln & 0 & 1 & $\mathrm{ND}$ & $\mathrm{ND}$ \\
H Trp-His-Gln & 2 & $\mathrm{ND}$ \\
\hline
\end{tabular}

Comparison of haplotype frequencies between patients and controls. ND = Not determined. *Chi-square test.

Table 3. Haplotype frequencies of the three $X R C C 1$ polymorphisms in patients and controls stratified by gender.

\begin{tabular}{|c|c|c|c|c|c|c|c|c|}
\hline \multirow[t]{2}{*}{ Haplotype } & \multicolumn{2}{|c|}{ Males } & \multirow[t]{2}{*}{ OR $(95 \% \mathrm{CI})$} & \multirow[t]{2}{*}{$\mathrm{P}^{*}$} & \multicolumn{2}{|c|}{ Females } & \multirow[t]{2}{*}{ OR $(95 \% \mathrm{CI})$} & \multirow[t]{2}{*}{$\mathrm{P}^{*}$} \\
\hline & $\begin{array}{c}\text { Controls } \\
(\mathrm{N}=168)\end{array}$ & $\begin{array}{c}\text { Patients } \\
(\mathrm{N}=130)\end{array}$ & & & $\begin{array}{l}\text { Controls } \\
(\mathrm{N}=72)\end{array}$ & $\begin{array}{c}\text { Patients } \\
(\mathrm{N}=110)\end{array}$ & & \\
\hline A Arg-Arg-Arg & 86 & 51 & 1.0 (Reference) & & 34 & 42 & 1.0 (Reference) & \\
\hline B Trp-Arg-Arg & 14 & 22 & $2.65(1.25-5.63)$ & 0.01 & 14 & 21 & $1.21(0.54-2.74)$ & 0.64 \\
\hline C Arg-Arg-Gln & 41 & 37 & $1.52(0.87-2.67)$ & 0.14 & 15 & 30 & $1.62(0.75-3.49)$ & 0.22 \\
\hline D Arg-His-Arg & 18 & 13 & $1.22(0.55-2.69)$ & 0.63 & 7 & 15 & $1.74(0.64-4.74)$ & 0.28 \\
\hline E Trp-Arg-Gln & 3 & 2 & ND & ND & 0 & 0 & ND & ND \\
\hline F Trp-His-Arg & 4 & 0 & ND & ND & 0 & 0 & ND & ND \\
\hline G Arg-His-Gln & 0 & 4 & ND & ND & 2 & 2 & ND & ND \\
\hline H Trp-His-Gln & 2 & 1 & ND & ND & 0 & 0 & ND & ND \\
\hline
\end{tabular}

Comparison of haplotype frequencies between patients and controls for gender. ND = Not determined. *Chi-square test.

\section{DISCUSSION}

Our findings suggest that independently 194Trp, 280His, and 399Gln alleles do not significantly increase the risk of ALL in Mexican mestizo children, a finding similar to that of Batar et al. (2009) in Turkish children for 194Trp and 399Gln alleles. Yet, it has been shown that $399 \mathrm{Gln}$ increases the risk of childhood ALL in Indians $(\mathrm{OR}=2.01,95 \% \mathrm{CI}=$ 1.19-3.40; $\mathrm{P}=0.009)$ (Joseph et al., 2005), Chinese ( $\mathrm{OR}=2.24,95 \% \mathrm{CI}=1.04-4.81)(\mathrm{Zhu}$ et al., 2005), and Thais $(\mathrm{OR}=1.67,95 \% \mathrm{CI}=1.20-2.33$; $\mathrm{P}=0.002)$ (Pakakasama et al., 2007). Additionally, Pakakasama et al. (2007) suggested that the 194Trp allele has a protective effect against ALL in the Thai population $(\mathrm{OR}=0.67,95 \% \mathrm{CI}=0.47-0.97 ; \mathrm{P}=0.03)$. The frequency of the polymorphisms was similar in males and females in our population. In this regard, Joseph et al. (2005) showed that carriers of polymorphic alleles had an elevated risk of ALL; however, significant differences for $194 \operatorname{Trp}(\mathrm{OR}=2.04,95 \% \mathrm{CI}=1.0-4.20 ; \mathrm{P}=$ $0.049)$ and for $399 \mathrm{Gln}(\mathrm{OR}=2.58,95 \% \mathrm{CI}=1.35-4.94 ; \mathrm{P}=0.004)$ were found only in male carriers. In another study, the 194Trp allele was associated with an increased risk of ALL in females (Batar et al., 2009). In our population, the haplotype B was associated with a greater risk of ALL in males $(\mathrm{OR}=2.65,95 \% \mathrm{CI}=1.25-5.63 ; \mathrm{P}=0.01)$.

Our finding that haplotype B (Trp-Arg-Arg) was significantly related to ALL (OR = $1.95,95 \% \mathrm{CI}=1.13-3.37 ; \mathrm{P}=0.016)$ contrasts with the reduced frequency of such haplotype in cases and the corresponding decreased risk of ALL $(\mathrm{OR}=0.62,95 \% \mathrm{CI}=0.42-0.90 ; \mathrm{P}=0.01)$ found by Pakakasama et al. (2007). Moreover, the higher albeit nonsignificant risk related to 
haplotype C (Arg-Arg-Gln) in our study is consistent with the significant risk of ALL (OR = $1.59,95 \% \mathrm{CI}=1.14-2.23 ; \mathrm{P}=0.008$ ) documented in Thai patients (Pakakasama et al., 2007).

On the other hand, no association was found between some of these XRCC1 alleles and acute myelogenous leukemia in Caucasians in the United Kingdom (Seedhouse et al., 2002), chronic myelogenous leukemia in Turkish people (Deligezer et al., 2007), malignant lymphomas in Japanese (Matsuo et al., 2004), follicular lymphoma in Danes and Swedes (Smedby et al., 2006), and non-Hodgkin's lymphoma in a Chinese population (Liu et al., 2009), whereas an increased risk related to the $399 \mathrm{Gln}$ allele was found for leukemia in a European population (Matullo et al., 2006), Hodgkin's lymphoma in an American population (El-Zein et al., 2009), and follicular lymphoma among Chinese heavy smokers (Liu et al., 2009). In contrast, a protective effect was observed for 194Trp allele in non-Hodgkin's lymphoma in Australians (Shen et al., 2007) and for 399Gln in therapy-related acute myelogenous leukemia (Seedhouse et al., 2002). Moreover, these XRCC1 polymorphisms have been extensively analyzed in several solid tumors in many populations, but controversial results have been reported (Hu et al., 2005).

There is no doubt that the inter-study discordances noted here are due to many factors including cancer type, tumor histology, selection criteria, wrong diagnosis, and of course ethnic background. It has been suggested that changes in the XRCC1 protein, mainly in amino acid 399, increase the susceptibility for tumor development via genomic instability (Lunn et al., 1999; Abdel-Rahman and El-Zein, 2000; Duell et al., 2000; Lei et al., 2002). Nevertheless, another study did not find any effect of Arg194Trp and Arg399Gln polymorphisms with regard to DNA damage (Pastorelli et al., 2002), even though it is not well known whether these polymorphisms produce a functional change in the protein. In any case, the risk of cancer depends on the involvement of several factors, and not only on the presence or combination of certain common genetic polymorphisms (Naccarati et al., 2007). Likewise, it has been suggested that several low penetrance genes, together with dietary effects, environmental exposure and individual immune system responses, could be the main factors predisposing to leukemia (Bolufer et al., 2006).

In conclusion, the differences between our results and those reported previously could be fortuitous and may be attributed to the size of the samples, different selection criteria or wrong diagnosis; nevertheless, such discordances could be due to the diverse genetic backgrounds among ethnic groups. Thus, further studies with larger samples may be necessary to elucidate the association between $X R C C 1$ polymorphisms and an increased risk of childhood ALL.

\section{ACKNOWLEDGMENTS}

We thank Dr. Horacio Rivera for the critical review of the manuscript. Research supported by the Universidad Autonoma de Tamaulipas through grant UAT07-BSAL-0206, by the Secretaria de Educacion Publica (SEP) by means of the Programa Integral de Fortalecimiento Institucional (C/PIFI-2006-29-32-78), and by the Consejo Nacional de Ciencia y Tecnologia (CONACyT) through grants 102564 and 102673 of the Convocatoria 2008 de Apoyo para Investigadores Nacionales para el Fortalecimiento de Actividades de Tutoria y Asesoria de Estudiantes de nivel Licenciatura.

\section{REFERENCES}

Abdel-Rahman SZ and El-Zein RA (2000). The 399Gln polymorphism in the DNA repair gene XRCC1 modulates the 
genotoxic response induced in human lymphocytes by the tobacco-specific nitrosamine NNK. Cancer Lett. 159: 63-71.

Batar B, Guven M, Baris S, Celkan T, et al. (2009). DNA repair gene XPD and XRCC1 polymorphisms and the risk of childhood acute lymphoblastic leukemia. Leuk. Res. 33: 759-763.

Bolufer P, Barragan E, Collado M, Cervera J, et al. (2006). Influence of genetic polymorphisms on the risk of developing leukemia and on disease progression. Leuk. Res. 30: 1471-1491.

Butkiewicz D, Rusin M, Enewold L, Shields PG, et al. (2001). Genetic polymorphisms in DNA repair genes and risk of lung cancer. Carcinogenesis 22: 593-597.

Deligezer U, Akisik EE and Dalay N (2007). Lack of association of XRCC1 codon 399Gln polymorphism with chronic myelogenous leukemia. Anticancer Res. 27: 2453-2456.

Duell EJ, Wiencke JK, Cheng TJ, Varkonyi A, et al. (2000). Polymorphisms in the DNA repair genes XRCC1 and ERCC2 and biomarkers of DNA damage in human blood mononuclear cells. Carcinogenesis 21: 965-971.

El-Zein R, Monroy CM, Etzel CJ, Cortes AC, et al. (2009). Genetic polymorphisms in DNA repair genes as modulators of Hodgkin disease risk. Cancer 115: 1651-1659.

Hu Z, Ma H, Chen F, Wei Q, et al. (2005). XRCC1 polymorphisms and cancer risk: a meta-analysis of 38 case-control studies. Cancer Epidemiol. Biomarkers Prev. 14: 1810-1818.

Hubbard TJ, Aken BL, Ayling S, Ballester B, et al. (2009). Ensembl 2009. Nucleic Acids Res. 37: D690-D697.

Joseph T, Kusumakumary P, Chacko P, Abraham A, et al. (2005). DNA repair gene XRCC1 polymorphisms in childhood acute lymphoblastic leukemia. Cancer Lett. 217: 17-24.

Krajinovic M, Labuda D, Mathonnet G, Labuda M, et al. (2002). Polymorphisms in genes encoding drugs and xenobiotic metabolizing enzymes, DNA repair enzymes, and response to treatment of childhood acute lymphoblastic leukemia. Clin. Cancer Res. 8: 802-810.

Lei YC, Hwang SJ, Chang CC, Kuo HW, et al. (2002). Effects on sister chromatid exchange frequency of polymorphisms in DNA repair gene XRCC1 in smokers. Mutat. Res. 519: 93-101.

Liu J, Song B, Wang Z, Song X, et al. (2009). DNA repair gene XRCC1 polymorphisms and non-Hodgkin lymphoma risk in a Chinese population. Cancer Genet. Cytogenet. 191: 67-72.

Lunn RM, Langlois RG, Hsieh LL, Thompson CL, et al. (1999). XRCC1 polymorphisms: effects on aflatoxin B1-DNA adducts and glycophorin. A variant frequency. Cancer Res. 59: 2557-2561.

Matsuo K, Hamajima N, Suzuki R, Andoh M, et al. (2004). Lack of association between DNA base excision repair gene XRCC1 Gln399Arg polymorphism and risk of malignant lymphoma in Japan. Cancer Genet. Cytogenet. 149: 77-80.

Matullo G, Dunning AM, Guarrera S, Baynes C, et al. (2006). DNA repair polymorphisms and cancer risk in non-smokers in a cohort study. Carcinogenesis 27: 997-1007.

Naccarati A, Pardini B, Hemminki K and Vodicka P (2007). Sporadic colorectal cancer and individual susceptibility: a review of the association studies investigating the role of DNA repair genetic polymorphisms. Mutat. Res. 635: 118-145.

Pakakasama S, Sirirat T, Kanchanachumpol S, Udomsubpayakul U, et al. (2007). Genetic polymorphisms and haplotypes of DNA repair genes in childhood acute lymphoblastic leukemia. Pediatr. Blood Cancer 48: 16-20.

Pastorelli R, Cerri A, Mezzetti M, Consonni E, et al. (2002). Effect of DNA repair gene polymorphisms on BPDE-DNA adducts in human lymphocytes. Int. J. Cancer 100: 9-13.

Ronen A and Glickman BW (2001). Human DNA repair genes. Environ. Mol. Mutagen. 37: 241-283.

Seedhouse C, Bainton R, Lewis M, Harding A, et al. (2002). The genotype distribution of the XRCC1 gene indicates a role for base excision repair in the development of therapy-related acute myeloblastic leukemia. Blood 100: 3761-3766.

Shen M, Purdue MP, Kricker A, Lan Q, et al. (2007). Polymorphisms in DNA repair genes and risk of non-Hodgkin's lymphoma in New South Wales, Australia. Haematologica 92: 1180-1185.

Smedby KE, Lindgren CM, Hjalgrim H, Humphreys K, et al. (2006). Variation in DNA repair genes ERCC2, XRCC1, and XRCC3 and risk of follicular lymphoma. Cancer Epidemiol. Biomarkers Prev. 15: 258-265.

Zhang Z, Wan J, Jin X, Jin T, et al. (2005). Genetic polymorphisms in XRCC1, APE1, ADPRT, XRCC2, and XRCC3 and risk of chronic benzene poisoning in a Chinese occupational population. Cancer Epidemiol. Biomarkers Prev. 14: 2614-2619.

Zhu R, Lu FJ, Zhang ZB, Zhai XW, et al. (2005). Association of genetic polymorphism of XRCC1 with susceptibility to acute childhood leukemia. Wei Sheng Yan. Jiu. 34: 300-302. 